\title{
Light and Heavy Chain Deposition Disease
}

National Cancer Institute

\section{Source}

National Cancer Institute. Light and Heavy Chain Deposition Disease. NCI Thesaurus. Code C158965.

A rare sub-type of monoclonal immunoglobulin deposition disease in which heavy and light chains deposition results in non-amyloid tissue deposits which may cause organ dysfunction 